\title{
The Limits of Agency: Emily Hobhouse's international activism and the politics of suffering
}

\author{
Rebecca Gill and Cornelis Muller
}

\section{Abstract}

This article pieces together the activism of the British welfare worker and feministpacifist Emily Hobhouse (1860-1926) during two largely unrecorded episodes of transnational activism: firstly her ministry of Cornish miners in Virginia, Minnesota, in the United States of America; and secondly, her interventions during the period of reconstruction following the South African War (1899-1902). The article endeavors to contextualize Hobhouse's advocacy and activism and offer a broader understanding of the limitations and restraints on her actions. Ultimately, her activism required a platform that was in the gift of political actors and establishment figures, and dependent on fluctuations within specific political and bureaucratic situations. Based on close inspection of undocumented material in both South African and British archives, the article investigates Hobhouse's repertoire of missionary and philanthropic roles within a wider context of humanitarian politics. It demonstrates how women's activism and their behind-the-scenes politicking informed political decision-making in modern imperial and international affairs. Hobhouse's work in the United States and South Africa embodied the evolution of the spiritual authority of missionary work into the new expert realm of transnational humanitarian advocacy and relief.

\section{Keywords}

Emily Hobhouse; South African War; women's activism; international humanitarianism; missionary work; transnational activism; South African reconstruction 


\section{Introduction}

This article considers aspects of the international activism of the British welfare worker and feminist-pacifist Emily Hobhouse (1860-1926). Best known today for her work with Boer women and children in the concentration camps of the South African War (1899-1902), Hobhouse has been the subject of numerous biographies - many of which celebrate her persistence, her pluck and her prescient concern for the fate of women and children in war. Other instances of her activism, such as her social-upliftment work in the United States during the 1890s, and her "peace work" following the war in South Africa and the First World War, are less well documented. Piecing together her extant correspondence in archives in the United Kingdom and South Africa, this article focuses on her advocacy work during two largely unrecorded episodes of transnational activism: her ministry of Cornish miners in Virginia, Minnesota, and her interventions during the period of reconstruction following the South African War. In so doing, it draws out the modes and methods available to women in this era to affect political transformation, particularly the privileging of suffering as the grounds for empathy, enlightenment and reconciliation, and considers the reception and negotiation of this politics of suffering. Notably, Hobhouse was concerned with white communities whose class position she felt to be imperiled; she only implicitly - and indifferently - addressed the broader race question in South Africa, unlike her contemporaries Charlotte Maxeke and Olive Schreiner.

Hobhouse's evocation of civilian suffering in South Africa as both a moral and political wrong contributed to the humanitarian imagination of the early twentieth century. Her letters reveal how a gendered set of missionary conventions underwrote her moral authority and the new role of the expert humanitarian advocate to which she increasingly laid claim. This "sense of self-consequence," to quote one biographer, rendered her impervious to criticism; but it also requires consideration of the possibilities and limitations of a vocation premised so resolutely 
on a responsiveness to human need, whether spiritual or material, for this served her well in certain contexts but left her maligned and marginalized in others. ${ }^{1}$ Certainly, biographical approaches to Hobhouse's agency - the primary medium through which her actions have been considered - are inadequate without awareness of the fluctuating political contingencies in which she operated. Instead, by investigating Hobhouse's repertoire of missionary and philanthropic roles within a wider context of humanitarian politics, this article illuminates something of the nature of women's activism and the behind-the-scenes brokerage of modern imperial and international affairs.

Without doubt, Emily Hobhouse was a woman of conviction. By her own account "a Gladstonian in foreign politics," she spent a good portion of her life engaged in transnational activism in the cause of international reconciliation and the eradication of the manifold corruptions of public life. ${ }^{2}$ She had an unshakable liberal faith in representative parliamentary government, an enlightened public sphere and the evils of militarism. This she combined with a "progressive" concern for social questions, women's right to representation, and the effects of war on civilian populations. These commitments would see her transfer her political hopes from the Liberal Party to the Independent Labour Party, most probably over Liberal leader Herbert Asquith's prevarications over female suffrage before the First World War. ${ }^{3}$ But first and foremost, Hobhouse set out in her public life as a committed Christian, with a strong evangelical calling and a zealous if undirected sense of "vocation."

For a woman alert to her legacy and the accuracy of the historical record, the relative dearth of properly contextualized historical accounts of her ideas and endeavors is notable. It

\footnotetext{
${ }^{1}$ Hall, That Bloody Woman, 5.

${ }^{2}$ Emily Hobhouse [EH] to L.T. Hobhouse, 14 September 1915 (Emily Hobhouse Papers (EHP), File: 1915/early 16, Box 1, Bodleian Library, Oxford University). Please note that the Emily Hobhouse Papers were undergoing cataloguing during the course of writing this article and so the Box numbers referred to here are temporary.

${ }^{3}$ Hobhouse was a friend of Ramsay Macdonald and the Independent Labour Party from the time of the South African War, when Macdonald himself visited the defeated territories and reported on their distress after the war. These associations continued into the First World War when Hobhouse wrote for the Labour Leader, and shared the pacifist stance of many prominent leaders of the Independent Labour Party.
} 
was left to friends and family to continue Hobhouse's manifold attempts at self-biography by publishing extracts from her letters and autobiographical writings. Ruth Fry, whom Hobhouse had first recruited to assist with her Boer Home Industries scheme following the South African War, was the first to edit and condense large sections of Hobhouse's unpublished draft memoir. ${ }^{4}$ Rykie Van Reenan, also with family connections to the Boer Home Industries scheme, followed suit with Emily Hobhouse: Boer War Letters. ${ }^{5}$ Meanwhile, Emily Hobhouse's great-niece Jennifer Hobhouse Balme's To Love One's Enemies, a book dedicated to "all seekers of Truth," used family papers to document Hobhouse's work during the South African War. ${ }^{6}$ Hobhouse Balme then sought "to show her innocence" in two further books, covering her great-aunt's work during the First World War. ${ }^{7}$ The favored medium for subsequent appraisals has been the popular biography, or most commonly hagiography, which give full vent to her singular idealism. Largely written without access to Hobhouse's private papers, these follow closely the contours of her life in the public eye. While drawing out some of the consistencies of her activism, they are understandably less revealing about the extent of her private politicking or the genesis of her ideas, tending to treat her life up to the outbreak of the South African War as merely a prelude. ${ }^{8}$ The most ready audience for the life of Hobhouse continues to be in South Africa, where there are no shortage of publications, films and public commemorations. ${ }^{9}$ In addition to popular narratives, military and political historians in South Africa have accorded Hobhouse recognition for her exposé of conditions in the British concentration camps of the South African War, but even nationalist historians of the period

\footnotetext{
${ }^{4}$ Fry, Emily Hobhouse.

${ }^{5}$ Van Reenen, Boer War Letters.

${ }^{6}$ Hobhouse Balme, To Love One's Enemies, viii.

${ }^{7}$ Ibid., Hobhouse Balme, dustjacket, Agent of Peace, and Living the Love. Jennifer Hobhouse Balme has deposited her family papers to the Bodleian Library, Oxford. For an interesting appraisal of EH's autobiographical writings, see: Stanley, "A Strange Thing is Memory".

${ }^{8}$ Beer, Angel of Love; Fisher, That Miss Hobhouse; Roberts, Those Bloody Women.

${ }^{9}$ Today EH retains the status of a heroine in South Africa, featuring, for example, in a gallery in the Anglo-Boer War museum in Bloemfontein and an annual ceremony at the Women's Memorial in Bloemfontein where her ashes are interred. Her most recent biographies are Eales' The Compassionate English Woman and Brits' Emily Hobhouse: Beloved Traitor.
} 
have largely ignored her contribution to the repatriation schemes and period of reconstruction which followed, possibly because her work of mediation renders her a more ambivalent figure.

In Britain, memory of Hobhouse quickly waned following her death in 1926; indeed, her attempts to create a legacy were compromised by the time of the First World War. Circumstances had by now changed. Her consistent faith in her ability to apprehend the facts (she attested to the relative good health of interned British civilians in Germany and Belgians under German occupation, reports which remained unsubstantiated) and her direct methods (for example, in seeking an unauthorised audience with the German Foreign Minister) blinded her to the extent to which she had become irrevocably tainted by allegations of "hysteria" and treachery, not least in the House of Commons. Furthermore, by 1914, the politics of suffering, now focused on alleged German atrocities in Belgium, found her estranged from former allies of the era of the South African War over the moral and political necessity of war with Germany. ${ }^{10}$ Politicians such as Louis Botha and Jan Smuts, now allied with the British war effort, no longer wished to be publicly associated with her - though both sustained a regular private correspondence - and her fellow "pro-Boer" C.P. Scott at the Manchester Guardian refused her articles. ${ }^{11}$

While traditional military histories of the South African War in Britain, from The Times' history onwards, have given scant consideration to the civilian experiences of the war or to Hobhouse, recent revisionist histories have refreshed our understanding of the wider war, in ways that intersect with the concerns of cultural and gender historians. Thus, while recent

\footnotetext{
${ }^{10} \mathrm{EH}$ was accused of "hysteria" in the Transvaal Leader a claim she was reported as refuting at a meeting of 26 August 1903 (EHP, unlabelled, undated, newspaper cutting, File: 1902-1903 letters and articles, Box 8); she was accused of "betraying her country" in the House of Commons, 31 October 1916.

${ }^{11}$ EH to Mrs Steyn, 31 July 1921 (EHP, File: Mrs Steyn 1920, Box 14; EH, manuscript journal, 1 June-April 1905, Box 14.) EH's attempts to put the suffering of the Boer women in the concentration camps on record was not always welcomed by those such as Smuts when seeking to work in closer union with the British government after the South African War. Within this period of reconstruction and debates over formal Union, EH's peace work and commemorative activity entered into a contested field of memory politics. See: Stanley, Mourning becomes. For letters written to the press during the South African War, see for example: Hobhouse, "The Boer Women and Children Prisoners," Manchester Guardian, 12 February 1901 and Hobhouse, "The Photograph of Lizzie van Zyl," The Westminster Gazette, 20 January 1902 (EHP, File: 1902-1903 letters and articles, Box 8).
} 
historical treatments of Hobhouse have continued to focus on her exposé of conditions in the concentration camps, thought now has been given to her gendered critique of militarism at the time of the South African War. ${ }^{12}$ But there has been little written about her wider activist networks, including her earlier work for the "pro-Boers," her post-war "peace work" in South Africa or Germany, and her part in the wider adult suffrage and international feminist movements. ${ }^{13}$ Certainly, Hobhouse has never entered the pantheon of feminist trailblazers. Hobhouse's great British rival Millicent Garrett Fawcett made sure of this in her own histories of the suffrage movement, which marginalized the splits at the time of the First World War and thus the contribution of pacifists such as Hobhouse. ${ }^{14}$ Nor, despite her connections with prominent feminists internationalists, such as the American Jane Addams and Dutchwoman Aletta Jacobs, does she feature in the literature on post-war feminist internationalism, or recent, largely sympathetic, histories of socialist women's transnationalism. This is possibly because she chose to work outside of established international organizations that came to prominence in the period after the First World War and possibly too because her class prejudices make her a less congenial subject. ${ }^{15}$

\footnotetext{
${ }^{12}$ See: Brown, "The Truest Form of Patriotism"; Krebs, "The Last of the Gentlemen's Wars," 38 and 56; Krebs, Gender, Race and the Writing of Empire; Liddington, Long Road to Greenham.

${ }^{13}$ Women, EH included, have been largely absent from the standard histories of the "pro-Boers", for example: Davey, The British Pro-Boers. For a corrective, see: Riedi, "The Women Pro-Boers," 92-115. On EH's Boer Home Industries Scheme, initiated in South Africa in 1905, see: Gill, Calculating Compassion, Chapter 6: "The Rational Application of Compassion? Relief, Reconstruction, and Disputes Over Civilian Suffering in the AngloBoer War, 1899-1902."

${ }^{14} \mathrm{EH}$ and Millicent Garrett Fawcett clashed over the need for the concentration camps in South Africa and over the question of Adult Suffrage (of which Hobhouse was a proponent). EH was not mentioned in the accounts of the constitutionalist suffrage movement written by her arch-rival Millicent Garrett Fawcett, who glossed over wartime schisms. On this point, see Vellacott's comments on the similar omission of a fellow anti-war suffragist: Vellacott, From Liberal to Labour with Women's Suffrage.

${ }^{15}$ EH resigned from the British Committee for Permanent Peace in 1915 on the grounds that it had "fallen into the hands of a clique" (a reference to the perceived influence of Millicent Garrett Fawcett) and instead sought individual affiliation with the Women's International League for Peace and Freedom, EH to Jane Addams, 4 November 1915 (EHP, File: 1915/early 1916, Box 1). For examples of the literature on women's internationalism, see: Sandell, “'A Real Meeting of the Women of East and West"; Hunt, "Towards a Gendered and Raced Socialist Internationalism," 321-341; Rowbotham, Rebel Crossing.
} 
But this has meant that singularity and exceptionality have been accorded her defining features, and the significance of her extensive correspondence has been overlooked. ${ }^{16}$ Fellow "pro-Boer" Dorothy Bradby wrote, upon receiving Hobhouse's correspondence from South Africa, that "we pass her letters around among the faithful like the Epistles of the early apostles."17 These letters provided the privileged testimony which gave the ballast to women's meetings, journalism and politically-minded "at homes," priming her followers with knowledge of civilian suffering in war and setting this forth as women's special area of responsibility. If, in her biographies, Hobhouse emerges as a heroine, it is largely for her success in speaking truth to power, and of battling the forces of militarism and bureaucratic inertia. But the genre allows less for the consideration of the convergences of political wills that made this possible, notwithstanding Hobhouse's protestations of political neutrality. Yet we need not think of Hobhouse only as influential in order to think that she is worthy of study. Her work was important for what she reveals about the transmission of spiritual authority to new humanitarian projects, and for the insight her letters provide into how these informal transnational networks interacted with official imperial relations. This reveals, in particular, the significance of a politics of suffering to the negotiation of new colonial nationalisms and domestic political constituencies.

\section{Virginia, Minnesota}

The death in early 1895 of Rev. Reginald Hobhouse, Archdeacon of Bodmin, freed his daughter Emily Hobhouse from her domestic and pastoral duties in rural Cornwall. Far from living a cloistered life, Hobhouse was well versed in the kind of social work carried out by women of

\footnotetext{
${ }^{16}$ On epistolary networks and the role of letters in facilitating political activism for women letter writers, see: Gring-Pemble, "Writing Themselves into Consciousness," 41-61; Stanley, Salter, and Dampier, "Olive Schreiner, Epistolary Practices and Microhistories," 577-597.

${ }^{17}$ E.D. Bradby to Mrs [?] Hobhouse, 20 January 1901 (EHP, File: Letters to myself \& Leonard January 1901 to May 30, 1901 from Joshua Rowntree, Aunt Mary, Bradbys and others - Courtneys, Box 5).
} 
her class. She was surrounded by family and friends, and, through extensive visits to her uncle and aunt at Hadspen house, had played hostess to many of the most prominent families in South West England. She was however restive, her strong sense of vocation lacking suitable cause. Using her contacts in the Church, and, it seems likely, from her brother L. T. Hobhouse's Oxford circles, Hobhouse sought to strengthen her sense of mission through interviews with a member of the Society of St John the Evangelist (known as the Cowley fathers). The Cowley fathers were a High Anglican order founded by Father Richard Meux Benson, devoted to spiritual uplift and good works with the poor in Oxford and missionary work overseas. Letters between Emily Hobhouse and the St John's Mission House in Oxford record the impression

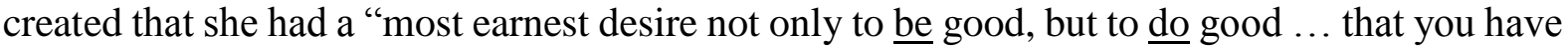
an ideal of what you would like to be to others, which is still somewhat indistinct and vague."18 But if her vocation was indistinct, it was also pressing, and indivisible from a desire to animate her life in a process of self-realization.

Ignoring the instruction to have faith, for "God will make known to you His purpose for you," Hobhouse was impatient for a letter of invitation from the Bishop of Minnesota, to whom she had appealed for an opening through her friend Mary Benson, wife of the Archbishop of Canterbury. ${ }^{19}$ Certainly, she appears to have been only a diffident theology student, requiring little of the spiritual guidance proffered by her mentor at the Mission House. She returned his books, he observed, "without telling me that you have read them; and without a desire, apparently, for others." 20 However, her patience was soon rewarded. Free now to fulfill her sense of vocation without the necessity of enduring theological instruction, Hobhouse set sail for the United States. By August 1895, she had arrived in Virginia, Minnesota with the intention of carrying "sweetness and light" to the Cornish emigres working in the local mines. ${ }^{21}$

\footnotetext{
${ }^{18}$ F.J. Robinson to EH, 17 April 1895 (EHP, File: vol ii from Jan 25 '95 to end of year, Box 19).

${ }^{19}$ Ibid., 18 April 1895.

${ }^{20}$ Ibid.

${ }^{21}$ Arthur Hobhouse to EH, London, 14 December 1895 (EHP, File: vol ii from Jan 25 '95 to end of year, Box 19).
} 
She was not alone in her quest of idealism and self-realization. Sheila Rowbotham, for example, has recently charted the transatlantic crossings of a group of British female radicals at the end of the nineteenth century. But whereas Rowbotham can celebrate the "altruistic hopes of free association, imagined communities and visions of a new society" of her chosen radicals, Hobhouse is unlikely to appear in such company. ${ }^{22}$ For while a radical Liberal in politics, and a strong supporter of female suffrage, her transnational crossings operated upon alternate lines of sociability and influence, ones drawn from the "old" society, less predisposed to social experimentation than to social reform and less concerned with social than political freedoms.

This intersection of pioneering spirit and sense of social propriety is most evident in Hobhouse's discomforted descriptions of the "democratic" spirit of the European emigres supposedly under her ministry. In one of her earliest letters home she wrote in shock on being treated equally and of her being "Miss Emily": "For here one is as good as another - a state of things I have always liked in theory but in practice it is very queer - There is nothing in England at all like it and I am brought up sharp at every turn." ${ }^{23}$ This spirit was perhaps the more unsettling among the Cornish community whom she had settled on as particularly worthy of her enthusiasm, for these were the group most expected to recognise her social distinction. Hobhouse quickly underscored these social divides by employing emigre Cornish women as her servants (she makes the distinction that in the United States these were known as "hired help") and was at pains to re-assure her family that she had quickly established her "ladylike" demeanor. ${ }^{24}$ In the space of a single page of a letter to her sister in England, she noted that the previous day had brought " 5 callers - Mary [her servant] was in fits of laughter over them," presumably for their aping of English customs. Hobhouse identified them as the respectable wives of local store-owners and "ladies who I believe teach school," at once mocking and

\footnotetext{
${ }^{22}$ Rowbotham, Rebel Crossings.

${ }^{23}$ EH to Maud Hebblethwaite, Virginia, 19 August 1895 (EHP, File: vol ii from Jan 25 '95 to end of year, Box 19).

${ }^{24}$ Ibid.
} 
acknowledging their attempt to adopt "English" manners and stratify their social superiors: "I find I am described here not only as a lady, that is no distinction, but as a 'perfect lady' which I gather implies someone not in search of dollars, a being quite fabulous in Virginia which is a town 'booming' where all the tagrag $[$ sic $]$ and bobtail come." 25

As historian Rhonda Semple has observed, women were ideally suited to the "joint evangelical imperative of faith and good work" of the kind that characterized late-nineteenth century missionary endeavors. This depended upon the modeling of standards; indeed, from the 1860 s, single women could undertake missionary work in their own right (rather than as the wives of male missionaries). ${ }^{26}$ Women such as Hobhouse, with no formal education or professional training, qualified by virtue of their "ladylike" personages. ${ }^{27}$ Fine manners were an imperative, as was female sociability and networking. In her early days, Hobhouse depended on connections with well-born American families and other women involved in mission work. Yet as Hobhouse's work attests, opportunities for personal agency and the fulfilment of a feminine sense of mission could also be limited by gendered conventions and expectations.

Laid out in 1892, the town of Virginia was in flux in the mid-1890s, precariously riding the economic tides that drew in workers to its five mines and lumber yards, but which receded leaving in their wake closures, debts, and migrations. In this fluctuating situation, Hobhouse's social position and personal conviction granted her significant latitude in her attempt to reform the civic life of its inhabitants. She remained in the town for just over a year, under the ambit of Bishop Whipple and the Episcopalian Church, and much of her energy was devoted to the unpopular temperance cause, inveigling against the saloons. As she reported, aghast, to a friend, "at present the main street is a disgrace - On either side the whole length are men in all

\footnotetext{
${ }^{25}$ Ibid., 9 September 1895.

${ }^{26}$ Semple, "Professionalising their faith," 118.

${ }^{27}$ Ibid., 124.
} 
stages of intoxication." Hobhouse would organize a band of women - "seven maids with seven mops" - to clean up the town, and a committee to open a reading room and library. ${ }^{28}$ Moreover, she reported,

The officers of the town and the Justices of the Peace all gained their seats only by votes bought with beer, and fear to them. About 40 saloons get the greatest part of the men's earnings at the mines and the Minsters dare not preach a sermon on the temperance question. $^{29}$

Her "perfect lady" persona and spiritual authority emboldened her outspoken criticism of local practices and dignitaries. "I verily believe I am the one person in the place not afraid of anybody," she informed her sister Maud. ${ }^{30}$ She compared herself favorably to the local clergy who "dare not speak out, they dare not give offence - for to lose even one member of their congregation is to lose a portion of their small salaries." ${ }^{31}$ Yet while being the "perfect lady" may have granted her independence and a platform - and certainly her civic endeavors, public speeches, and Sunday sermons to the miners were reported approvingly in The Virginian, the town's local newspaper - her relationship to the public sphere in Virginia was, in other ways, highly dependent.

On the one hand, Emily Hobhouse's vocation remained unmet because the imagined transnational links between home and mission did not exist: the Cornish miners she had hoped to uplift did not materialize as a stable group ripe for lessons in moral reform from the "old" society. Rather they were mobile - many having moved on once the mines began to close and the few that remained lived intermingled with other emigre nationalities. "I find myself amongst a mass of foreign miners, chiefly Swedes and Finns and Austrians," she reported to her sister-in-law Nora Hobhouse, "the work I came to do is not here to be done." Instead, she became unwittingly mired in a scramble between the various denominations - Presbyterian,

\footnotetext{
${ }^{28}$ EH to "Carrie," 29 October 1895 (EHP, File: vol ii from Jan 25 '95 to end of year, Box 19)

${ }^{29}$ Ibid., EH to Maud Hebblethwaite, 28 September 1895.

${ }^{30}$ Ibid.

${ }^{31}$ Ibid., EH to "Carrie" 29 October 1895.
} 
Methodist, Episcopalian - for influence over these new communities. ${ }^{32}$ Refusing to do the bidding of the Episcopalian Archdeacon - "The truth is he wanted a curate to work up the Church in this place and pounced upon me, ... [b]ut curate of Virginia I will not be" - she asserted her own agency to enact a broader faith and social mission. This was based to a large degree on her feminine theology and sense of her own eminence, yet she lacked the financial resources, influence and infrastructure of a more established position in the Church. ${ }^{33}$

On the other hand, it appears that the town had a polite tolerance for feminine concerns. While the novelty of this "ladylike" evangelizing was tolerated by the town's officials, this was less a marker of successful conversion than it was a function of the place of temperance and social reform in local politics. Those public men who did grant her a platform, chief among them Mr Jackson, a prominent local storeowner and mayor of the town (and later, for a while, Hobhouse's fiancé), were criticized by the saloon owners who saw this as an attack upon their interests. Jackson's support for Hobhouse's library schemes were recorded in The Virginian. ${ }^{34}$ As she reported to her aunt Mary Hobhouse:

With regard to the saloon keepers I feel no fear. Several of them I know personally and am friendly with them and Americans are so very civil to womankind - they appear to think it quite natural that I should be doing Temperance work, and say nothing against it, but they are very very angry with the men who support me and have notified some of these men that they mean to spoil their businesses if they continue to work publicly with me. The plot is beginning to thicken now, because the Municipal Elections are drawing near. ${ }^{35}$

At this time, Jackson was considering running as representative in the forthcoming elections, and their joint campaign to establish reading rooms and temperance halls unintentionally brought her mission work into the wider electoral politics of the town.

\footnotetext{
${ }^{32}$ Ibid., EH to Nora Hobhouse, 16 September 1895.

${ }^{33}$ Ibid.

${ }^{34}$ Anon., "The Library: Everything will be in readiness in two weeks," 7 November 1895. This report recorded that EH was Treasurer and Mr Jackson Secretary of The Virginia Public Library association. Local clergy were also prominent on the committee.

${ }^{35}$ EH to Mary Hobhouse, 28 January 1896 (EHP, File: vol ii from Jan 25 '95 to end of year, Box 19).
} 
These controversies demonstrate something of the complex nature of female agency in mission circles. On the one hand, operating in liminal, mutable, spaces, these women had a surprising freedom of action to evangelize and partake of good works. On the other, granted a platform by powerful others, and unwittingly part of wider civic, religious and political battles, such missions could be adopted - and by the same token dropped - according to whim. Emily Hobhouse's influence was thus highly dependent. But her time in Virginia, Minnesota is revealing of the discretionary social leadership embedded in this particular form of missionary endeavor. It demonstrates the social qualifications for international welfare work, such as educational work among the town's children and her voluntary sick nursing, by which Hobhouse was able to "model" by example the gendered virtues central to these forms of transnationalism.

\section{South Africa}

Emily Hobhouse would come, in many ways, to embody the transmission of evangelical conviction and gendered social authority from missionary work into the early days of international humanitarianism, a sphere in which she soon lay claim to considerable expertise. ${ }^{36}$ The evolving repertoire of women's witnessing of suffering and missionary-humanitarian practices at this specific moment of late-nineteenth and early-twentieth-century imperial politics was most evident in her public interventions over the suffering of Boer civilians during the South African War. ${ }^{37}$ In South Africa, this inheritance was demonstrated in her sense of a special feminine intimation of suffering, her spreading of a social gospel, and in her attempt to meld word and deed in acts of public deliverance. Yet Hobhouse's association with South

\footnotetext{
${ }^{36}$ On the topic of wartime civilian distress, EH would write to Smuts that "It is my subject," EH to Smuts, 19 December 1918 (EHP, File: "Swiss relief fund papers and letters", Box 14). On the importance of spiritual concerns on women's social activism outside of organized religion, see: Midgley, "Women, religion and reform"; Lewis, Women and Social Action.

${ }^{37}$ For reflections on the relationship of humanitarianism to late nineteenth and early twentieth century practices, see: Skinner and Lester, "Humanitarianism and Empire," 729-447.
} 
Africa did not end with the declaration of peace, for in the aftermaths of war she attempted to revitalize her wartime networks in projects of restitution and reconciliation. Nor was her spiritual authority and ministry of suffering demonstrated in religious form. Unlike in the United States, Hobhouse did not present herself as a missionary or attempt to "save souls" in South Africa. But this was not a personal turning away from God, for Hobhouse's idealism appears consistently as a form of Christian ethics. Rather, it seems likely that Hobhouse understood the limitations, and unpopularity, of British missionary work in South Africa. Instead, she chose to deal with Boer politicians and Dutch Reformed Church ministers, who were a key intermediary, with the secular skills of a social investigator and relief worker.

When peace finally came to South Africa at the end of May 1902, Hobhouse found herself back in England where she continued to advocate on behalf of the defeated Boers. The scorched earth policy initiated by Lord Kitchener in March 1901, which intended to cut off food supplies to the Boer commando forces, had led to the destruction of 30000 farms and 40 towns in the two former Republics. The British military removed civilians to concentration camps and destroyed all livestock not appropriated for the war effort. ${ }^{38}$ A mammoth task in addressing the destruction and devastation wrought by three years of bitter conflict confronted the British administrations in the newly renamed Orange River Colony and the Transvaal. The authorities established repatriation departments in both colonies to oversee the relocation of civilian communities to their districts of origin and the reunification of Boer prisoners of war with their families. ${ }^{39}$

The Peace Treaty of Vereeniging made provision for a "free grant of three million pounds." This would assist in "the restoration of the people to their homes and supplying those who, owing to war losses are unable to provide for themselves, with food, shelter, and the

\footnotetext{
${ }^{38}$ For more information on the scorched earth policy, see: Spies, Methods of Barbarism?; Pretorius, ed., Scorched Earth.

${ }^{39}$ Beak, The Aftermath of the War; Van Rensburg, "Die Ekonomiese Herstel van die Afrikaner," 230-6; Katzenellenbogen, "Reconstruction in the Transvaal," 341-61.
} 
necessary amount of seed, stock, implements etc, indispensable to the resumption of their normal occupations." It further provided that all receipts issued by the military during the war would be presented to a Judicial Commission for verification as to evidence of War losses suffered. Lastly, the British Government would make loans available to those in need, free of interest for two years after which three present interest would be added per annum. ${ }^{40}$

From the outset, the Boers deemed the financial package promised by the British authorities as insufficient to aid in the reconstruction of the war-torn communities. The Boer leaders to emerge after the war interpreted the "Free Grant" as a non-repayable amount of money for compensating the so-called Bittereinders and their families for war losses suffered. However, Lord Alfred Milner, High Commissioner for South Africa and Governor of the Orange River Colony and the Transvaal, interpreted the clause to mean that the money was a loan which recipients would pay back within a set period after receiving compensation. Much to the dismay of the Bittereinders, he also resolved that the grant would be accessible only by those Boers who had taken an oath of allegiance to the Crown and had fought on the British side during the war. ${ }^{41}$

Hobhouse's role in this period of reconstruction has received little attention from her biographers. Similarly, more general texts accounting for the rebuilding of the two former Boer Republics after the war and the making of Union only give slight consideration to Hobhouse's agency during this period. This could be because historians are generally of the consensus that, despite some difficulties, the repatriation and reconstruction efforts were commendable. $^{42}$ Milner's socio-political engineering attempts to force the Boers into the British Empire either by their own will or by means of "political extinction" overshadowed the

\footnotetext{
${ }^{40}$ In total, the final cost of repatriation and resettlement amounted to $£ 16,500,000$. For a detailed analysis of the different interpretations of the "Free Grant" and a breakdown in expenditure of the total amount, see: Kriel, "Emily Hobhouse en die naweë van die Anglo-Boere Oorlog," Chapter 8: "Repatriasie en Kompensasie," 152-82.

${ }^{41}$ Beak, The Aftermath of the War; Van Rensburg, "Die Ekonomiese Herstel van die Afrikaner," 230-6; Katzenellenbogen, "Reconstruction in the Transvaal," 341-61.

${ }^{42}$ Van der Walt, Wiid and Geyer, Geskiedenis van Suid-Afrika; Muller, 500 Years, 322.
} 
apparent success of his reconstruction efforts. ${ }^{43}$ The historiography of this period thus tends to focus on Milner's attempts at reconciling the British and Afrikaners, his economic policies, his role in laying the foundation for Union, his failed British immigration policy, his subsequent attempt to anglicize the two former Republics, the Chinese labor debacle and his entrenchment of white supremacy at the expense of black South Africans. ${ }^{44}$ Where Hobhouse's role during this period has received some attention, it is as part of an overarching heroine narrative and mostly acts as a bridge between her activism during the war and her subsequent social welfare work in establishing spinning and weaving schools in the Transvaal and Orange River Colony from 1905 onwards. ${ }^{45}$ Yet, as Hobhouse's letters disclose, the question of repatriation was far from settled. Hobhouse herself deemed it "a failure." Instead, her letters reveal a carefully calibrated politics of suffering on this question, evident in the private correspondence, but obscured by the Boer leaders' public pronouncements, and thus, in turn, absent from historiographical accounts of official imperial affairs of the period. ${ }^{46}$

On returning to South Africa in May 1903, Hobhouse set off on a fact-finding mission to the interior. After arriving in Bloemfontein, she went on tours of the rural districts of the Orange River Colony followed by the Transvaal to ascertain the extent of the reconstruction needs of the Boers. She relied on the hospitality of friends and strangers, particularly Dutch Reformed Ministers, within the Boer communities to host her during her travels through the two colonies. Although her correspondence reveals that not all people suffered to the same degree, it is evident in her letters that she did encounter great hardship among the families and communities she visited. During the tour, Hobhouse was feted in a number of public rituals. At Heidelberg, for instance, concentration camp orphans garlanded her with flowers following

\footnotetext{
${ }^{43}$ Le May, British Supremacy in South Africa, 158. See, also: Thompson, A Wider Patriotism.

${ }^{44}$ Giliomee, The Afrikaners, 264-265; Dubow, "Colonial nationalism," 53-85; Hyam and Henshaw, The Lion and the Springbok.

${ }^{45}$ An exception to this is the study by Kriel, "Emily Hobhouse en die naweë van die Anglo-Boere Oorlog."

${ }^{46}$ Draft Memoir, (EHP, “Documents relating to S.A. work in 1903 and the failure of Repatriation,” Box 13).
} 
Botha's speech at the first mass meeting of the Boers after the war in July 1903. During this time, Hobhouse engaged in acts of public memorialization, including a visit to the camp burial sites at Middelburg, and the collection of diaries of women who had been in the camps. The Boer leaders, in contrast, did not seek to publicly connect the suffering of the present to the suffering of the concentration camp days. ${ }^{47}$

Hobhouse specifically blamed "Red Tapism" and the failure of British officials and Boers to understand each other for the desperate situations that she encountered in the two colonies. She argued that corruption and mismanagement further marred the process. ${ }^{48}$ The Rand Daily Mail published an article in July 1903 pointing out that up to that stage the authorities had spent more money on administering the relief effort than on issuing compensation or supplies to the destitute and needy. ${ }^{49}$ Hobhouse believed that the repatriation committees were hampered in their efforts as the system "was hedged with impossible rules."50 She also criticized the issuing of compensation and aid as linked to the promise of a "Free Grant." She wrote to her aunt, "The three million being a 'free gift' as stated in the Peace terms is a joke. Except some scanty rations to widows and orphans I can hear of no 'gift'. Security is demanded for every atom of help." ${ }^{51}$ The Boer leader, General Louis Botha, supported her assessment. In a letter to Emily Hobhouse's brother, Leonard Hobhouse, published in The Times in July 1903, Botha also claimed that the repatriation efforts of Lord Alfred Milner had been "a complete and dismal failure." 52

However, the Peace Preservation Act circumscribed the Boer leader's criticism of the British repatriation efforts. ${ }^{53}$ Smuts and Hobhouse criticized Botha, stating that the letter

\footnotetext{
${ }^{47}$ Ibid., (EHP, "In the Transvaal. Heidelberg Vergadering and Eastern Trek. Original first draft”, Box 12).

${ }^{48}$ Ibid., (EHP, "Repatriation. Military Receipts. Settlers. The Elusive £3,000,000 12).

49 Anon., Rand Daily Mail, 29 July 1903.

${ }^{50}$ EH to Lady Hobhouse, 18 June 1903, Van Reenen, Boer War Letters, 208.

${ }^{51}$ Ibid., 10 June 1903,193.

${ }^{52}$ Anon., The Times (London), 15 July 1903. See also: (EHP, File: "Repatriation. Military Receipts. Settlers. The Elusive $£ 3,000,000$," Box 12).

${ }^{53}$ The Act was informally known in Afrikaans/Dutch as the Hou-Jou-Bek-Wet (Keep your trap shut Act) and also the Coercion or Monstrous Act in English. The Act imposed peace-time censorship and suppressed criticism of
} 
underplayed the full extent to which people continued to suffer during this time. ${ }^{54}$ Hobhouse, however, informed her brother:

General Botha ... takes just the same view of the country and its wants as I do. At the time that letter was written he was conducting negotiations with the Governor upon the very subject of the distressed people. They dare not write openly and support me lest it should be thought they are using me as their political agent.

In consequence of the latter, it appears that whereas the Boer leaders were willing to associate with Hobhouse privately - indeed, were willing to use her as a proxy to redress the "repatriation muddle" on their behalf - they did not wish to be associated with her public appeals for fear of inflaming their relationship with the British authorities or detracting from their broader negotiating position. Despite Botha's letter, it is evident that the Boer leaders did not rely on the repatriation issue to criticize Milner's administration publicly. At Heidelberg the two main issues on the agenda were Milner's anglicization policy and his resolve to import Chinese labor for the mines of the Witwatersrand. ${ }^{55}$ Smuts and Botha politely rejected Milner's attempt to reconcile the Boer leaders to his cause by offering them seats on the Transvaal Legislative Council. They did not want to be politically associated with Milner and thus be comprised in the eyes of the Afrikaners. ${ }^{56}$ The Boer leaders thus constantly had to tread lightly in their critique of the Milner administration. Hobhouse was aware that Botha and Smuts lived under the fear of potential arrest at any time, although she did not believe the authorities would resort to this. ${ }^{57}$

It is thus within this political context that Hobhouse undertook her tour of the interior and made her appeals for assistance. Hobhouse claimed to have encountered a prevalent mood of sullenness among the Boers, which manifested in an increasing alienation between the authorities and the Boer people. The fact that the authorities had closed the repatriation depots

\footnotetext{
the British Administration with threat of banishment without trail or imprisonment of 21 days. See, Van Reenen, Boer War Letters, 481, note 5.

${ }^{54}$ EH to Lady Hobhouse, 12 September 1903, Van Reenen, Boer War Letters, 286.

${ }^{55}$ Le May, British Supremacy in South Africa, 161.

56 Ibid., 159.

${ }^{57}$ EH to Leonard Hobhouse, 2 September 1903, Van Reenen, Boer War Letters, 281.
} 
and therefore stopped the distribution of aid at the end of May 1903 worsened the situation. Thus, within the limitations of her own means and the relief funds to which she had access, she tried to alleviate some of the more pressing needs of the destitute. Hobhouse ascribed a large portion of the blame for the repatriation system's dysfunctionality to the magistrates appointed to chair the committees. She argued that they had too many other duties to effectively deal with the humanitarian needs of the communities they served. Hobhouse felt that the local clergy would have better administered this task, as the Boers had an inbred mistrust of the officials appointed to the boards. But limited funds and Hobhouse's conviction that it was not wise to simply provide financial aid to the needy hampered her efforts. As far as she could help, she would rather provide the desperate and destitute with foodstuff and other practical items. In certain cases, she would leave money with local ministers and church officials to administer on her behalf. ${ }^{58}$ It is evident that Hobhouse wanted to prevent a reliance on charity and government welfare taking root within the Boer communities, a belief also shared by Milner. $^{59}$

However, as much as Hobhouse blamed the British for the dire situation that confronted her, she also reserved some criticism for the attitude of the Boer people in the aftermath of the war. Firstly, she criticized them for making a tactical error of judgment by placing all their hope on aid and help from the authorities. She argued that all Boers, regardless of status or creed, had "to set aside all thought of 'Free Gift' Compensation or Military Receipts, and face life trusting to his own arm and such help as Cape relatives might offer. The delay and despair were injuring their prospects more than any money from the Government could put right." In order to bring about relief for the suffering, Hobhouse proposed that those Boers who had

\footnotetext{
58 Ibid., EH to Lady Hobhouse, 15 June 1903, 202.

${ }^{59}$ Duncan to Lieutenant Governor, 3 October 1903 (National Archives of South Africa (NASA), Transvaal Archival Repository (TAB), Archive of the Lieutenant Governor (LTG), 86, 92/7, Part One); Milner to Colonial Secretary, 9 September 1903 (NASA, TAB, LTG, 86, 92/7, Part One).

${ }^{60}$ EH to Lady Hobhouse, 15 June 1903, Van Reenen, Boer War Letters, 202.
} 
access to land should approach capitalists and relatives in the Cape Colony to take out mortgages on their land and that this money had to be used for reconstruction purposes. ${ }^{61}$

Hobhouse realized that whereas the Boers who owned land had greater access to the means needed to rebuild their lives, the landless class of Boers did not. This realization also confronted Hobhouse with issues relating to race and class within this community. Her proposal that impoverished white young Boer women had to enter service was generally met with contempt and dismissed. These women refused to do any work considered to be the duty of black servants. She wrote to her aunt, "They have but two ways whereby to earn their living - sewing and teaching ... if near a town they will also iron, but they will not wash. That is Kaffir [sic] work." Hobhouse's criticism of this situation was rooted in her comparative interpretation of experiences in Britain, where manual work and "self-help" was linked to notions of virtue and strength of character rather than subservience. She was adamant in her assertion that "their old customs must be altered owing to the great upheaval the country has undergone, and pressure of circumstances must drive them to take service."62

With disparagement reserved for both Boer and Briton, Hobhouse thus set out to make use of the various platforms accorded her to bring about relief. As recalled in her draft memoir, her sense of her privileged intimation of suffering and quality of empathy engendered her selfimage as conduit, "the [Dutch Reformed Church] Ministers and I were in touch with the living, suffering, human beings, the Repatriation Headquarters knew them only as 'cases' in terms of figures."63 She realized that she would have to spur the British government into providing more aid, but without resorting to overt criticism due to the consequence she may face under the terms of the Peace Preservation Act. It is thus at this point during her return to South Africa that Hobhouse's informal politicking started to take effect. Having familiarized herself with

\footnotetext{
${ }^{61}$ Ibid., 18 June 1903, 193.

62 Ibid., undated, 211.

${ }^{63}$ Draft Memoir (EHP, “Compensation, reparation, settlers,” Box 12).
} 
the specific circumstances which would require attention, she penned a letter to the South African News in August 1903. In it, she appealed to the people in the Cape Colony for donations so that she could obtain a "sufficient supply of meal" and money to buy mules or oxen to assemble plowing teams to help farmers work their fields in the various districts. ${ }^{64}$ Although the plea was successful and she collected $£ 3,000$ in the first two weeks after publication, it also brought Hobhouse into direct conflict with the authorities.

Hobhouse informed her aunt that to her "astonishment this appeal has brought the whole of South Africa down upon my head."65 Nevertheless, Hobhouse dismissed the criticism expressed in what she labeled the "Jingo papers" and believed that the "publicity has aroused (the anger, perhaps, but also) the activity of the Government." ${ }^{96}$ Egged on by the evident success of the risk she had taken, Hobhouse also made a direct appeal to her supporters in the Liberal Party in Britain. She wanted the government to reopen the repatriation depots and once again provide food on credit. British MP, Leonard Courtney, who successfully advocated the matter to the Colonial Secretary took up her appeal. The Colonial Secretary subsequently telegraphed Milner wanting answers, stating:

Miss Hobhouse cables her friends here that the distress is most alarming in certain districts, and asks them to extort permission for Repatriation food to recommence. She adds that Boer representations to local authorities have failed. I have replied that I cannot interfere with your discretion, and she must make application to you direct with full particulars. ${ }^{67}$

Milner went on to admit that there was still much poverty among the Boers, but claimed that "if cases of actual want have occurred it is because they have not been brought to our notice." Nevertheless, Milner instructed the acting Lieutenant General of the Orange River Colony, H.J. Wilson, and the Colonial Secretary of the Transvaal, Patrick Duncan, to follow-up on the matter. Wilson denied that there was "alarming distress" in the Orange River Colony, but

\footnotetext{
${ }^{64}$ Hobhouse, South African News, 16 August 1903.

${ }^{65}$ EH to Lady Hobhouse, 4 September 1903, Van Reenen, Boer War Letters, 283.

${ }^{66}$ Ibid.

${ }^{67}$ Colonial Secretary to Milner, 7 September 1903 (NASA, TAB, LTG, 86, 92/7, Part One).

${ }^{68}$ Ibid., Milner to Colonial Secretary, 9 September 1903.
} 
concluded that Hobhouse could have come across cases of "apparent distress" among the poorer Boer classes. ${ }^{69}$

Yet, despite Wilson's defense, Hobhouse now prided herself on the fact that she had "upset their apple-cart." ${ }^{, 70}$ Clearly her intervention to the press and her telegram to London had resulted in the desired outcome. This was confirmed when she received a "friendly" note from Duncan to request a meeting. ${ }^{71}$ Duncan was a prominent member of Milner's so-called Kindergarten, a group of Oxford-trained young men that Milner had assembled in South Africa to help him in his post-war reconstruction efforts. ${ }^{72}$ Hobhouse initially viewed Duncan as "meek" and a "poor young man" who was futilely trying to defend, in her opinion, the indefensible. Duncan, however, assured Hobhouse that he would "whip his boards into shape" and that the Repatriation Department would again make ploughing teams available for those farmers needing assistance. Hobhouse welcomed this "eleventh hour" intervention, but remained skeptical as to whether Duncan would make good on these promises. ${ }^{73}$ She later reflected in her memoirs that he had "listened with sympathetic interest" and, after their meeting, sent her information as to how many widows his department had helped. Duncan admitted that "as regards certain districts very little had been done." He further requested that Hobhouse send him the names of those individuals who were in desperate need. He also allowed Hobhouse access to the official figures spent on ploughing teams by the department. In light of these figures, Hobhouse prided herself that her teams were able to help farmers "at far less cost."74 Yet Duncan dismissed her idea of lending ploughing teams to farmers without any supervision as in the previous year this had "resulted in the loss of most of the animals

\footnotetext{
${ }^{69}$ Ibid., Lieutenant General, Bloemfontein to Milner, 9 September 1903.

${ }^{70} \mathrm{EH}$ to Leonard Hobhouse, 2 September 1903, Van Reenen, Boer War Letters, 280.

${ }^{71}$ Ibid., 260.

${ }^{72}$ Nimocks, Milner's Young Men; Thompson, A Wider Patriotism. See, also Van der Schyff, "Sir Patrick Duncan" in De Kock, ed., Dictionary of South African Biography, I, 258-60.

${ }^{73}$ EH to Leonard Hobhouse, 2 September 1903, Van Reenen, Boer War Letters, 280.

${ }^{74}$ Draft Memoir (EHP, File: “Compensation. Reparation. Settlers. Original Draft,” Box 12).
} 
lent." Despite being "anxious" about the matter, he was willing to give the "plan a trial if substantial men will come forward and make themselves responsible for the care of the teams." $" 75$

In the interim Milner also took remedial action and informed the Colonial Secretary that the Repatriation Boards, which had ceased to issue food on credit, would again resume this practise for "those who cannot otherwise maintain themselves." developments, Hobhouse informed the ministers and church officials that "no one need to be without some food" and that she "no longer [had] any right as food is concerned to appeal at this moment to charity."77 Duncan continued to correspond with Hobhouse and she provided him with detailed suggestions as to how the reconstruction effort could be improved. ${ }^{78}$ Spurred on by Hobhouse's accusations of maladministration, Duncan also undertook a tour of the South Western and Western districts of the Transvaal towards the end of September. Duncan noted various improvements in the districts since the end of the war, but also reported that the crippling drought of 1902 had worsen the devastation wrought by the war. ${ }^{79}$

Hobhouse's close interaction with Duncan thus led to him obtaining first-hand knowledge of where there was still pressing need among the people in the Transvaal Colony. By this time Hobhouse's skepticism of Duncan had abated; she wrote to her aunt on sending him her letters, saying, "I fancy he will act on them more or less thoroughly." 80 However, despite Duncan's evident sincere attempts to address her concerns and Hobhouse's own role as "conduit," she later reflected in her memoirs:

\footnotetext{
${ }^{75}$ Duncan to EH, 10 September 1903 (EHP, File: "Return to England and 1904,” Box 12).

${ }^{76}$ Milner to Colonial Secretary, 9 September 1903 (NASA, TAB, LTG, 86, 92/7, Part One).

${ }^{77}$ EH's circular to all Church Councils in the former Republics, copy dated 11 October 1903 (EHP, File: "Return to England and 1904," Box 12).

${ }^{78}$ Draft Memoir (EHP, File: “Compensation. Reparation. Settlers. Original Draft,” Box 12) and EH to Duncan, 26 September 1903 (EHP, letter, Box 12).

79 "Report on a visit to the South Western and Western Districts of the T[rans]V[aa]L by P[atrick] D[uncan]" (The Sir Patrick Duncan Papers, BC294, University of Cape Town Libraries, Cape Town, A38.14, 30 Sept 1903 [?], 3).

${ }^{80}$ EH to Lady Hobhouse, 27 September 1903, Van Reenen, Boer War Letters, 293.
} 
Indeed, it was for me a most trying and puzzling time. On the one hand were the ministerial promises like Chamberlain's and some pale reflections of these which were typed in reams of paper and issued by the Transvaal Government, and there was Mr. Duncan's sympathetic concern and evident goodwill. On the other hand I had the evidence of my own eyes and ears, supported by ministers and leading men in every district I had visited, and yet chasm would not get bridged; help was dilatory, grants were not fulfilled... ${ }^{81}$

Hobhouse relied on the church officials in the various districts to inform her of the provisioning of aid to the widows. When these figures did not correspond with Duncan's official figures, she confronted him, claiming that information received was "evidently a glaring untruth or misrepresentation." ${ }^{82}$ Duncan responded defensively to Hobhouse's accusation. He stated that his figures amounted to assistance which had been "approved" by the government and not which the widows in question had necessarily obtained. He blamed the beneficiaries for not making the effort to obtain their approved aid. He was emphatic that "there is no desire to mislead anybody or to misrepresent what the Government has done." ${ }^{\text {, } 3}$

Hobhouse, however, remained defiant that she was "justified" in her expectations that the widows had received aid, as the document she had in her possession clearly stated they had been "assisted under the Full Grant." 84 As Hobhouse added, "all these things may not be intended as "untruths," but they undoubtedly "misrepresent the position of the widows." She remained scathing of the excessive bureaucratic redundancy embedded in the relief programs. Duncan later admitted that there indeed had been a discrepancy, but that it was merely due to a "hitch." He reasserted that he took offense to the phrasing used by Hobhouse's source and defended his administrators by reminding her of the "confusion and uncertainty" with which the project started. He felt "on the whole ... the work has been done well." ${ }^{85}$ Hobhouse wrote to Duncan a few days before returning to Britain, saying, "I fear that I hurt your feelings ...

\footnotetext{
${ }^{81}$ Draft Memoir (EHP, File: “Compensation. Reparation. Settlers. Original Draft,” Box 12).

${ }^{82}$ Duncan to EH, 9 October 1903 (EHP, File: "Return to England and 1904,” Box 12).

${ }^{83}$ Ibid., 23 November 1903.

${ }^{84}$ EH to Duncan, 28 November 1903 (EHP, File: "Return to England and 1904," Box 12).

85 Duncan to EH, 8 December 1903 (EHP, File: "Documents relating to S.A. Work in 1903 and the failure of Repatriation,” see also: (EHP File: “Repatriation. Military Receipts. Settlers. The Elusive £3,000,000,” Box 12).
} 
and if so I am very sorry." 86 As much as Hobhouse reserved ample praise for Duncan later in her memoir, she felt that the bureaucratic nature of the authorities' relief efforts ultimately failed as it did not consider the "human point of view." $" 87$ But she maintained that her prodding had in fact done more good than harm as it had implored Duncan to investigate the situation and ascertain for himself the true state of affairs. ${ }^{88}$ It is evident that Hobhouse did not enjoy the same cordial relationship with the Free State officials which developed with Duncan. "I do not think Mr. Duncan can be too highly commended for his wise and prompt actions," she addressed to her confidant Mrs Steyn. "Had his spirit and his energy and diligence permeated more the local boards much suffering could have been saved and much poverty averted. It made me wish that a Mr Duncan could have been found in your Free State Administration also at that painful time." 89

Back in London, Hobhouse continued to assert pressure on the authorities, but with mixed results. As testament to her own sense of purpose, she remained determined to get things done. Colonial Secretary Alfred Lyttelton granted her a meeting at the end of February. ${ }^{90}$ At this meeting Hobhouse raised several points regarding the relief efforts in the two colonies. She reasserted that her interaction with Duncan had "resulted in a slight improvement," but felt that the government could do more, especially for the widows of the Orange River Colony. ${ }^{91}$ She also advocated for the pay-out of military receipts, even though many Boers did not qualify for compensation as they had not voluntarily surrendered during the war. ${ }^{92}$ She further took up the case of the former South African Republic Police officers who had been deprived of

\footnotetext{
${ }^{86}$ EH to Duncan, [?] December 1903 (EHP, File: "Documents relating to S.A. Work in 1903 and the failure of Repatriation," Box 13, 1).

${ }^{87}$ Draft Memoir (EHP, File: “Repatriation. Military Receipts. Settlers. The Elusive £3,000,000,” Box 12).

${ }^{88}$ EH to Duncan, [?] December 1903 (EHP, File: "Documents relating to S.A. Work in 1903 and the failure of Repatriation," Box 13,).

${ }^{89}$ Draft Memoir (EHP, File: “Oxford Papers, Compensation. Reparation. Settlers. Original Draft," Box 12).

${ }^{90} \mathrm{EH}$ to Lyttelton, 29 February 1904 (NASA, TAB, CT, 45, 3646/04).

${ }^{91}$ Precis to meeting with Lyttelton, 3 March 1904 (NASA, TAB, Archive of the Colonial Treasury (CT), 45, $3646 / 04)$.

${ }^{92}$ Milner to Lyttelton, 12 November 1904 (NASA, TAB, Archive of the Governor of the Transvaal Colony (GOV), 208, 18/04).
} 
their occupation and who were still owed salaries by the former Republican government. ${ }^{93}$ Lastly, she presented the Colonial Secretary with a number of individual cases which she wanted investigated. ${ }^{94}$

The Colonial Secretary asked Milner to investigate these issues; he followed up with a detailed report on the cases Hobhouse presented. But he dismissed these, claiming that nearly all the cases related to "men who have themselves failed to observe the universal rules of war" and therefore did not qualify for compensation. Milner urged Lyttelton to use the information in the report "in such a way that we are not compelled to reconsider every settled case." $\mathrm{He}$ argued, "I can hold out no hope either of the early completion of the business of compensation or of any general increase of satisfaction to the public."95 In January 1905, Lyttelton informed Hobhouse that he concurred with Milner that "there is no ground for interference in these cases. $" 96$

Once again, it is evident that Hobhouse's activism depended on the willingness of officials and politicians to engage with her. Her relationship with Patrick Duncan can perhaps be singled out in this regard as a case where her ideals and methods had served her well. Although he did not always agree with Hobhouse, he nevertheless followed up and made enquiries about the cases she brought to his attention and acted to address problems where he too agreed that there was merit in her assertions. Yet, at the same time, this interaction benefited Duncan by giving him the opportunity to be seen as "doing" something even if he did not in the end implement any of her suggestions, thus highlighting the magnanimity of British rule while he could still manage the possible repercussions which came with Hobhouse's reputation. That the British Administration in South Africa were willing to be seen publicly to work alongside Hobhouse offered useful demonstration of their benevolence

\footnotetext{
${ }^{93}$ EH to Lyttelton, 16 March 1904 (NASA, TAB, CT, 45, 3646/04).

${ }^{94}$ Precis to meeting with Lyttelton, 3 March 1904 (NASA, TAB, CT, 45, 3646/04).

${ }^{95}$ Milner to Lyttelton, 12 November 1904 (NASA, TAB, GOV, 208, 18/04).

${ }^{96}$ F. Graham on behalf of Lyttelton to Hobhouse, 6 January 1905 (NASA, TAB, GOV 95/94).
} 
and operated as a public act of restitution in its own right. This is evident in a Reuters's dispatch from Pretoria, which Hobhouse recorded approvingly in her draft memoir:

soon after the publication of my appeal I had "the opportunity of placing the facts before one of the ablest and humane and sympathetic members of the Transvaal Administration." Mention that arrangements had been made for continuing assistance on credit and that the Department would plough for the people at low charge, the message ended: - "The Administration is heartily to be commended for its prompt and sympathetic actions and upon being strong enough to disregard the silly attacks made upon Miss Hobhouse by journalistic and other critics who are ignorant or worse." $" 97$

It is also evident that Hobhouse's role as "conduit" between the suffering Boer people and the British authorities was one that worked equally well for Duncan, who utilized Hobhouse as an intermediary with Dutch ministers of the church to communicate government directives.

It is therefore important to account for the context in which the authorities took cognizance of Hobhouse during this stage of her relief work in South Africa. Her reputation (for better or worse) elicited a reaction that could not be ignored. The authorities realized this and it is evident that Milner's willingness to engage with her enquiries sprouted from her appeals to the press and her politically connected contacts in Britain. Yet, by the beginning of 1905, it is also evident that despite the Lyttelton's assurance to Hobhouse that cases deserving attention should be directly brought to the Colonial Office's attention for investigation by the authorities in South Africa, Milner had a need to draw a line under the matter. At this point, for her "pro-Boer" supporters in Britain, the suffering of the Boers had lost its political import in proving British imperialism to be "corrupt." Post-war suffering was much more mundane, a product less of tyranny than of "red tapism." Much to Hobhouse's chagrin, her supporters in Britain had by now turned their attention to the suffering in Macedonia, which they believed was more likely to galvanize the Liberal Party in Britain, in the way that the exposure of Boer suffering during the war had done originally. ${ }^{98}$

\footnotetext{
${ }^{97}$ Draft Memoir (EHP, “Compensation, reparation, settlers,” Box 12).

${ }^{98}$ Ibid., (EHP, “Return to Cape Colony,” Box 12).
} 
Hobhouse must have realized this too, and her focus once again shifted to another practical solution to bring about relief among the Boer communities. In early 1905 she once again boarded a ship to South Africa, this time to establish home industries with a focus on spinning and weaving as well as lace making in the two colonies. She had hope that this endeavor would enable Boer women to earn a more sustainable income for their destitute and impoverished communities in comparison to the restricted relief offered by the "Repatriation Muddle."

\section{Conclusion}

Hobhouse's work in the United States and South Africa embodied the evolution of the spiritual authority of missionary work into the new expert realm of transnational humanitarian advocacy and relief, in which word and deed were similarly one. With this inheritance came not only gendered assumption about women's special qualities for this vocation - and those of English, upper-class women's in particular - but also understandings of social leadership replete with hierarchical class assumptions. Indeed, human wants and sufferings, often understood in racial and class terms, were the necessary pre-requisite upon which these roles were established. With her absolute faith in a rational public sphere, but also with a certain political astuteness of her own, Hobhouse valued her relationship with the Manchester Guardian and other newspapers, for it was by making the facts known, she believed, that reform would follow.

And it was precisely when she detected a severance of word and deed in her dealings with political figures that she was most disillusioned. This was particularly true of the political calculations over post-war Boer suffering made by the Boer leaders, Milner, Duncan, and the "pro-Boers" in Britain. It would be for this reason, like many contemporary female reformers of the period, that Hobhouse supported female suffrage, and campaigned on this cause in South Africa and Britain:

...for me faith in Ministers and their promises was broken by all I had lived through. These experiences were mainly responsible for my ardent support of the 
Suffragist movement. I hoped that women might bring higher and purer standards into public life, less personal ambition and more thorough attention to the detail ... of administration. ${ }^{99}$

With the rise of Afrikaner nationalism in the late 1920s and 1930s, the politics of suffering in South Africa would be configured once again, this time into a claim for protection and deliverance though racial segregation (with which Hobhouse's own legacy in South Africa became entangled). At this juncture, women's concentration camp narratives gained a particular prominence; though not for the reasons of reform, reconciliation and peace that Hobhouse had hoped. ${ }^{100}$ Hobhouse's negotiations around instances of post-war suffering, and the decision of Smuts and Botha not to take up the public fight for repatriation for risk of antagonizing Milner when they could influence Hobhouse herself to do so, demonstrate the extent to which this was a selective and contingent politics of suffering, galvanized by moments when political wills converged.

As Alan Lester has argued, government officials were not simply petitioned by external non-state actors, rather "humanitarian dispositions and rationalities extended to those exercising governance, and not simply those seeking to influence them."101 On the one hand, traditional biographical approaches are insufficient to fully capture the emerging conventions around missionary-humanitarian endeavors at this juncture of imperial and international affairs, and recount Hobhouse's endeavors simply as battles fought and lost against intractable politicians. On the other, treatments of South African history that rely on "high" political and diplomatic sources alone, and by doing so present only the results of political calculations, miss the influence of women's behind-the-scenes politicking, but also the points of genuine convergence, in the calibration of these decisions.

\footnotetext{
99 Ibid., (EHP, "Rough draft. Kronstad [sic] - Ventersburg, to the Paarl," Box 12). On this point, see: DeVries, "More than paradoxes to offer," 199.

${ }^{100}$ Stanley, Mourning becomes, 81.

${ }^{101}$ Lester and Dussard, Colonization and the Origins of Humanitarian Governance, 2.
} 


\section{Author names and affiliation}

Rebecca Gill - Department of Music, Humanities and Media, University of Huddersfield, Huddersfield, United Kingdom (‥gill@hud.ac.uk)

Cornelis Muller - International Studies Group, University of the Free State, Bloemfontein, South Africa (cornelis.muller@spu.ac.za)

\section{Notes on contributors}

Rebecca Gill is a Senior Lecturer at the University of Huddersfield and researches the history of humanitarian organizations and transnational activism. She is a currently co-investigator, with Cornelis Muller and Helen Dampier (Leeds Beckett University), on the Emily Hobhouse letters project: $\underline{w w w . e m i l y h o b h o u s e l e t t e r s p r o j e c t . w o r d p r e s s . c o m . ~}$

Cornelis Muller is a Research Associate in the International Studies Group at the University of the Free State and a lecturer in History at Sol Plaatje University in Kimberley, South Africa. He holds a Ph.D. in Africa Studies from the University of the Free State and an MA in History from the University of Pretoria. His research interests include broader histories and politics of Empire and Imperialism in Africa with a specific interest in late-nineteenth- and earlytwentieth-century state formation in South Africa.

\section{Disclosure Statement}

No potential conflict of interest was reported by the authors. 


\section{References}

Anon., Rand Daily Mail, 29 July 1903.

Anon., "The Library: Everything will be in readiness in two weeks," The Virginian, 7 November 1895.

Anon., The Times (London), 15 July 1903.

Beak, G.B. The Aftermath of the War. An account of the Repatriation of the Boers and Natives in Orange River Colony, 1902-1904. London: Edward Arnold, 1906.

Beer, Frank H. Angel of Love: Emily Hobhouse, 1860-1926. Michigan, USA: Charaton Books, 2002.

Brits, Elsabe. Emily Hobhouse: Beloved Traitor. Cape Town: Tafelberg, 2016.

Brown, Heloise. "The Truest Form of Patriotism": Pacifist Feminism in Britain, 1870-1902. Manchester: Manchester University Press, 2003.

Davey, A. The British Pro-Boers, 1877-1902. Cape Town: Tafelberg, 1978.

DeVries, Jacqueline. "More than paradoxes to offer: Feminism, history and religious cultures" in Sue Morgan and Jacqueline DeVries, eds., Women, Gender and Religious Cultures in Britain, 1800-1940. London: Routledge, 2010.

Dubow, Saul. "Colonial nationalism, The Milner Kindergarten and the Rise of "South Africanism', 1902-1910," History Workshop Journal 43 (Spring, 1997) 53-85.

Eales, Robert. The Compassionate Englishwoman, Emily Hobhouse in the Boer War. Claremont: UCT Press, 2015.

Fisher, John. That Miss Hobhouse. London: Secker and Warburg, 1971.

Fry, A. Ruth. Emily Hobhouse: A Memoir. London: J. Cape, 1929.

Giliomee, Hermann. The Afrikaners: Biography of a People. Cape Town: Tafelberg, 2009.

Gill, Rebecca. Calculating Compassion: Humanity and Relief in War, Britain 1870-1914. Manchester: Manchester University Press, 2013.

Gring-Pemble, Lisa M. "Writing Themselves into Consciousness: Creating a Rhetorical Bridge Between Public and Private Sphere," Quarterly Journal of Speech 84, No.1, (1998), 41-61.

Hall, John. That Bloody Woman: The turbulent life of Emily Hobhouse. Cornwall: Truran, 2008.

Hobhouse Balme, Jennifer. Agent of Peace: Emily Hobhouse and her Courageous Attempt to End the First World War. Stroud: The History Press, 2015.

- Living the Love: Emily Hobhouse post-war (1918-1926). Victoria, Canada: Friesen Press, 2016.

- To Love One's Enemies. Cobble Hill, Canada: Hobhouse Trust, 1994.

Hobhouse, Emily. "The Boer Women and Children Prisoners," Manchester Guardian, 12 February 1901

. South African News, 16 August 1903.

The Brunt of War and where it fell. London: Methuen, 1902.

"The Photograph of Lizzie van Zyl," The Westminster Gazette, 20 January 1902

Hunt, Karen. "Towards a Gendered and Raced Socialist Internationalism: Dora Montefiore Encounters South Africa (1912-1914)," African Studies, 66, No. 2-3 (Dec. 2007), 321-341. Hyam, R. and P. Henshaw. The Lion and the Springbok: Britain and South Africa Since the Boer War. Cambridge: Cambridge University Press, 2003. 
Katzenellenbogen, S.E. "Reconstruction in the Transvaal," in Peter Warwick., ed., The War in South Africa. The Anglo-Boer War 1899-1902. London: Longman, 1981, 341-61.

Krebs, Paula. "'The Last of the Gentlemen's Wars': women in the Boer war concentration camp controversy," History Workshop Journal xxxiii, (1992), 38-56.

- Gender, Race and the Writing of Empire: Public Discourse and the Boer War. Cambridge: Cambridge University Press, 1999.

Kriel, J.D. "Emily Hobhouse en die naweë van die Anglo-Boere Oorlog. 'n Studie in altrïsme en pasifisme," Unpublished D.Phil. Thesis, University of the Free State, Bloemfontein, 1957.

Le May, G.H.L. British Supremacy in South Africa, 1899-1907. Oxford: Clarendon Press, 1965.

Lester, Alan and Fae Dussard. Colonization and the Origins of Humanitarian Governance: Protecting Aborigines Across the Nineteenth-Century British Empire. Cambridge: Cambridge University Press, 2014.

Lewis, Jane. Women and Social Action in Victorian and Edwardian England. Aldershot: Edward Elgar, 1991.

Liddington, Jill. Long Road to Greenham: Feminism and Anti-militarism in Britain from 1820. London: Virago, 1989.

Midgley, Clare. "Women, religion and reform," in Sue Morgan and Jacqueline deVries (eds), Women, Gender and Religious Cultures in Britain, 1800-1940. London, Routledge, 2010.

Muller, C.F.J. 500 Years: A History of South Africa. Pretoria \& Cape Town: Academica, 1969. Nimocks, W. Milner's Young Men: The "Kindergarten" in Edwardian Imperial Affairs. Durham: Duke University Press, 1968.

Pretorius, Fransjohan. ed. Scorched Earth. Cape Town: Human \& Rousseau, 2001.

Riedi, Eliza. "The Women Pro-Boers: Gender, Peace and the Critique of Empire in the South African War," Historical Research 86, No. 321 (Feb 2013), 92-115.

Roberts, Brian. Those Bloody Women: Three Heroines of the Boer War. London: John Murray, 1991.

Rowbotham, Shelia. Rebel Crossings: New Women, free lovers and radicals in Britain and the United States. London: Verso, 2016.

Rupp, Leila J. Worlds of Women: The History of the International Women's Movement. Princeton: Princeton University Press, 1997.

Sandell, Marie. "A Real Meeting of the Women of East and West': Women and Internationalism in the Interwar Period," in Daniel Laqua, ed. Internationalism Reconfigured: Transnational Ideas and Movements Between the Wars. London: I. B. Tauris, 2011.

Semple, Rhonda. "Professionalising their faith: Women, religion and the cultures of mission and empire," in Sue Morgan and Jacqueline de Vries, eds. Women, Gender and Religious Culture in Britain, 1800-1940. London: Routledge, 2010.

Skinner, Rob and Alan Lester. "Humanitarianism and Empire: New Research Agendas," The Journal of Imperial and Commonwealth History 40, No. 5, (2012), 729-447.

Spies, Stephanus B. Methods of barbarism? Roberts and Kitchener and Civilians in the Boer Republics January 1900-May 1902. Cape Town: Human \& Rousseau, 1978.

Stanley, Liz, Andrea Salter and Helen Dampier. "Olive Schreiner, Epistolary Practices and Microhistories: A Cultural Entrepreneur in a Historical Landscape," Cultural and Social History 10, No. 4, (2013), 577-597. 
Stanley, Liz. “"A Strange Thing is Memory': Emily Hobhouse, Memory Work, Moral Life and the 'Concentration System', 'South African Historical Journal 52, No. 1, (2005), 60-81.

- Mourning becomes: ... post / memory and commemoration and the concentration camps of the South African War. Manchester: Manchester University Press, 2006.

Thompson, J. Lee. A Wider Patriotism: Alfred Milner and the British Empire. New York: Routledge, 2016.

Van der Schyff, P.F. "Sir Patrick Duncan" in W.J. de Kock, ed. Dictionary of South African Biography I, Cape Town: Tafelberg, 1976.

Van der Walt, A.J.H., J.A. Wiid and A.L. Geyer. Geskiedenis van Suid-Afrika. Kaapstad: Nasou, 1971.

Van Reenen, Rykie. Emily Hobhouse: Boer War Letters. Cape Town: Human and Rousseau, 1984.

Van Rensburg, Abraham P.J. "Die Ekonomiese Herstel van die Afrikaner in die Oranjerivierkolonie, 1902-1907," Archives Yearbook for South Africa, 30(2), Pretoria: Government Printer, 1967.

Vellacott, Jo. From Liberal to Labour with Women's Suffrage: The Story of Catherine Marshall. London: McGill-Queen's University Press, 1993. 